\title{
Increased Connective Tissue Extracellular Matrix in the op/op Model of Osteopetrosis
}

\author{
Zaher A. Radi ${ }^{a}$ Roberto E. Guzman ${ }^{b}$ Rosonald R. Bell ${ }^{b}$ \\ a Pfizer Global Research and Development, Drug Safety Research and Development, St. Louis, Mo., \\ b Pfizer Global Research and Development, Groton, Conn., USA
}

\section{Key Words}

op/op mice $\cdot$ Extracellular matrix $\cdot$ Histochemistry .

Histopathology $\cdot$ Macrophage colony-stimulating factor

\begin{abstract}
Mice that are homozygous for the recessive osteopetrosis spontaneous mutation (op/op) develop severe osteopetrosis due to a defect in the production of macrophage colonystimulating factor (M-CSF) and a deficiency in monocyte-derived osteoclasts. Our study describes a novel soft tissue finding in an osteopetrosis ( $\mathrm{B} 6 \mathrm{C} 3 \mathrm{Fe}$ a/a-Csf ${ }^{\circ \mathrm{op}} / \mathrm{J}$ ) mouse model. Tissues were obtained from $\mathrm{B} 6 \mathrm{C} 3 \mathrm{Fe} a / \mathrm{a}-\mathrm{Cs} f 1^{\circ \mathrm{p}} / \mathrm{J}$ mice and age-matched wild-type mice, processed for hematoxylin and eosin sections, and comprehensive light microscopic tissue evaluation was performed. Mutant mice had characteristic traits of op/op deficiency including missing incisors and domed skulls. Histologically, the bone marrow cavity was effaced by interweaving thick bony trabeculae consistent with osteopetrosis. An increase in a finely granular, basophilic interstitial extracellular matrix (ECM) was observed in the subcutaneous connective tissue of the op/op mice when compared with controls. Histochemically, the ECM was negative with periodic acid Schiff and stained dark blue with alcian blue at a pH of 2.5, indicating that it is composed primarily of nonsulfated glycosaminoglycans (GAGs). This work suggests an increased ECM that is composed mainly of GAGs
\end{abstract}

located in the subcutaneous tissue in op/op mice. This increase in ECM may be related to altered matrix production or turnover because of changes in M-CSF production.

Copyright $\odot 2009$ S. Karger AG, Basel

\section{Introduction}

Mice homozygous for the recessive osteopetrosis mutation (op/op mice) have osteopetrosis and a restricted capacity for bone remodeling and resorption due to osteoclast deficiency [1]. These mice typically have hypocalcemia, hypophosphatemia, generalized reduction in the number of macrophages as well as reduced size and number of osteoclasts, but no abnormalities in osteoblasts [2, 3]. On gross pathologic examination, $o p / o p$ mice are toothless, have generalized skeletal sclerosis, domed skulls, short tails, lower body weight and growth rate, and lack incisors. On histologic examination of the bone, the proximal end of the tibia and the distal end of the femur are widened, the diaphysis does not have a well-defined cortex, the zone of hypertrophied chondrocytes occupies half the thickness of the epiphyseal plate and the maturation of the mandibularincisor extracellular matrix (ECM) does not take place $[3,4]$. Partial or complete correction of these defects has been observed following treatment with colony-stimulating factor (CSF-1) [1, 5-7].

\section{KARGER \\ Fax +41613061234 E-Mail karger@karger.ch} www.karger.com

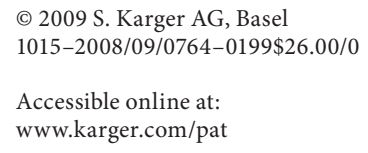

Zaher A. Radi, $\mathrm{PhD}$

Pfizer Global R\&D

700 Chesterfield Parkway West

St. Louis, MO 63017 (USA)

Tel. +1 636247 1218, Fax +1 636247 1114, E-Mail zaher.radi@pfizer.com 


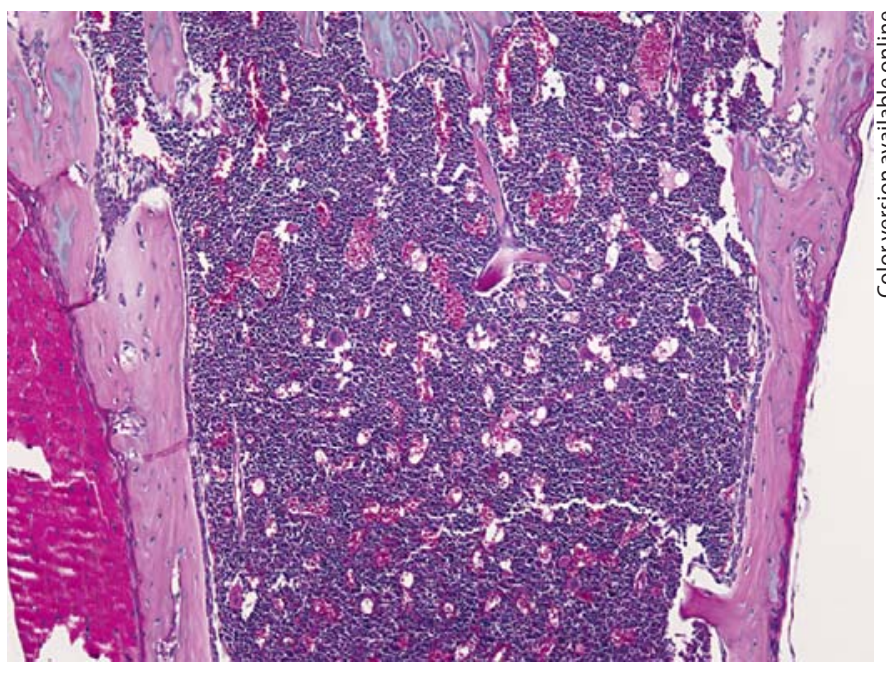

Fig. 1. Histopathology of a bone section from a control mouse. HE. $\times 10$

Connective tissue, one of the most abundant and widely distributed tissues in the body, is metabolically active and provides structural support. Connective tissues have 2 major components: cells and ECM. Fibers and ground substance, which exist outside the cells, are collectively called the ECM. Three major types of fibrous proteins appear in connective tissue: collagen, elastin and reticular fibers.

The ECM component of connective tissue is the dominant one and consists of organic material called ground substance within which fibers are embedded. In addition, there are structural glycoproteins of ECM. Ground substance is composed of glycosaminoglycans (GAGs) and proteoglycans. GAGs include hyaluronic acid, chondroitin sulfate, dermatan sulfate, heparin sulfate and keratin sulfate. GAGs are important components of the connective tissue that bind water and minerals. GAGs can normally be found in various tissues such as cartilage, heart valves and eye vitrous fluid.

Published reports on the histopathologic characterization of the op/op osteopetrosis mouse model have been limited to the skeletal system. Using histopathologic and histochemical evaluation, we evaluated various tissues and characterized changes observed in this osteopetrosis animal model. We report novel alterations in the soft connective tissues of the skin that were characterized by a generalized increase in connective tissue GAGs in the subcutaneous tissues. The relevance of this finding in this important model of human disease is that it fills a gap in the knowledge on abnormalities in ECM in osteope-

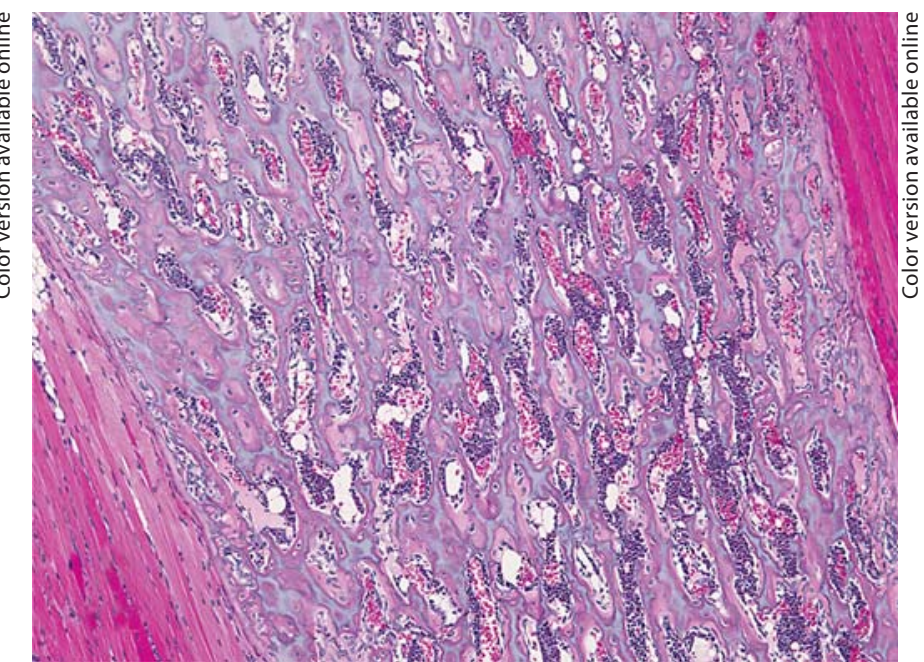

Fig. 2. Histopathology of a bone section from an op/op mouse. Note that the bone marrow cavity is effaced by interweaving thick bony trabeculae consistent with osteopetrosis. HE. $\times 20$.

trosis. In addition, it provides the foundation for potential future studies looking at mechanisms of this process and its relevance to human disease.

\section{Materials and Methods}

\section{Study Animals}

Four-week-old female B6C3Fe a/a-Csf $f 1^{o p} / \mathrm{J}$ mice $(\mathrm{n}=8)$ were used in the study. Mice exhibited the classic traits of op/op deficiency: missing incisors and domed skulls. Age-matched female mice $(\mathrm{n}=8)$ were used as controls. The mice were obtained from Jackson Labs (Bar Harbor, Me., USA). All procedures were in compliance with the Pfizer Ann Arbor Laboratories Animal Care and Use Committee.

\section{Study Tissue Samples and Histopathology}

At the time of necropsy, the following tissues were collected: adrenal, bladder, bone, diaphragm, esophagus, eyes, heart, kidney, liver, lung, lymph node, muscle, ovaries, pancreas, sciatic nerve, spleen, skin, thymus, tongue, uterus and vagina. Tissues were fixed in $10 \%$ neutral buffered formalin for $24 \mathrm{~h}$ and embedded in paraffin wax. Paraffin sections, $3 \mu \mathrm{m}$ thick, were prepared routinely and stained with hematoxylin and eosin and examined by light microscopy.

\section{Histochemical Staining}

To better characterize the increased matrix in the subcutaneous tissue, various carbohydrate stains (periodic acid Schiff, PAS, and alcian blue) were applied to skin sections using standard methods [8]. Three-micrometer sections were cut from formalinfixed, paraffin-embedded blocks, mounted on positively charged glass slides and dried. For the alcian blue staining, different $\mathrm{pHs}$ were used $(0.4,1.0$ and 2.5$)$. 


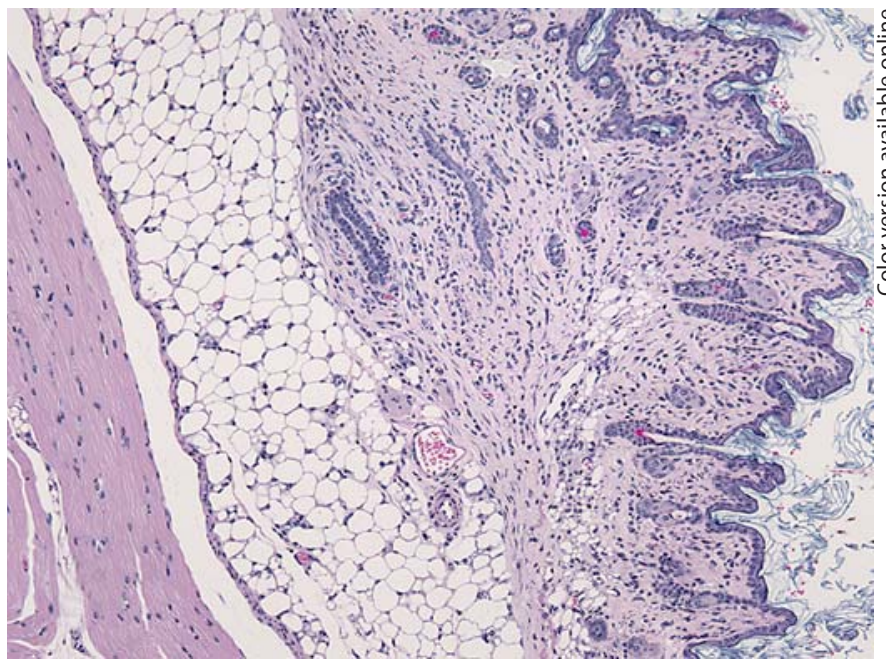

Fig. 3. Histopathology of the subctutaneous tissue from a control mouse. HE. $\times 10$.

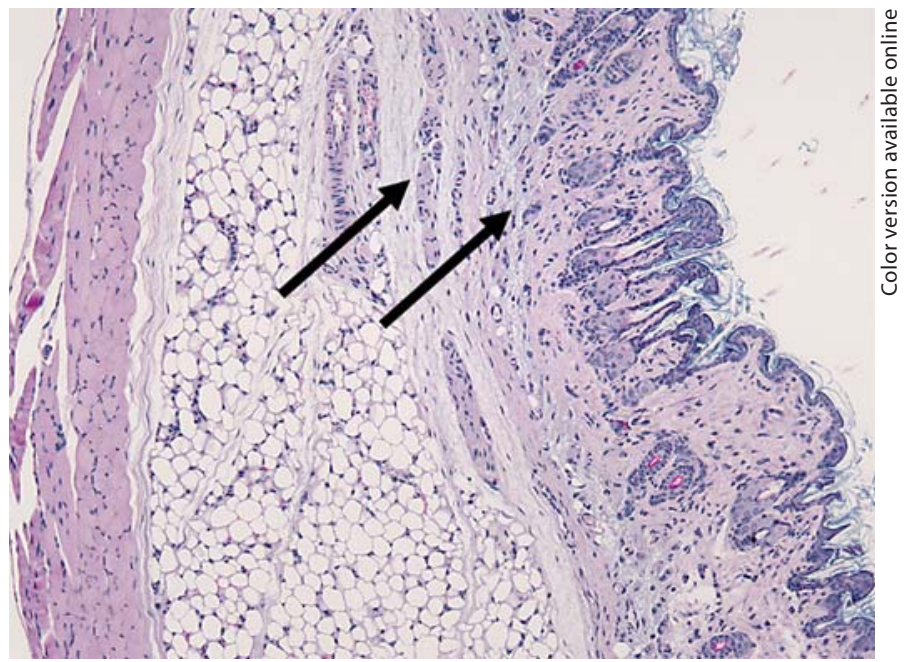

Fig. 4. Histopathology of the subcutaneous tissue from an $o p / o p$ mouse. Note the increase in a finely granular, basophilic interstitial ECM (arrows). HE. $\times 10$.

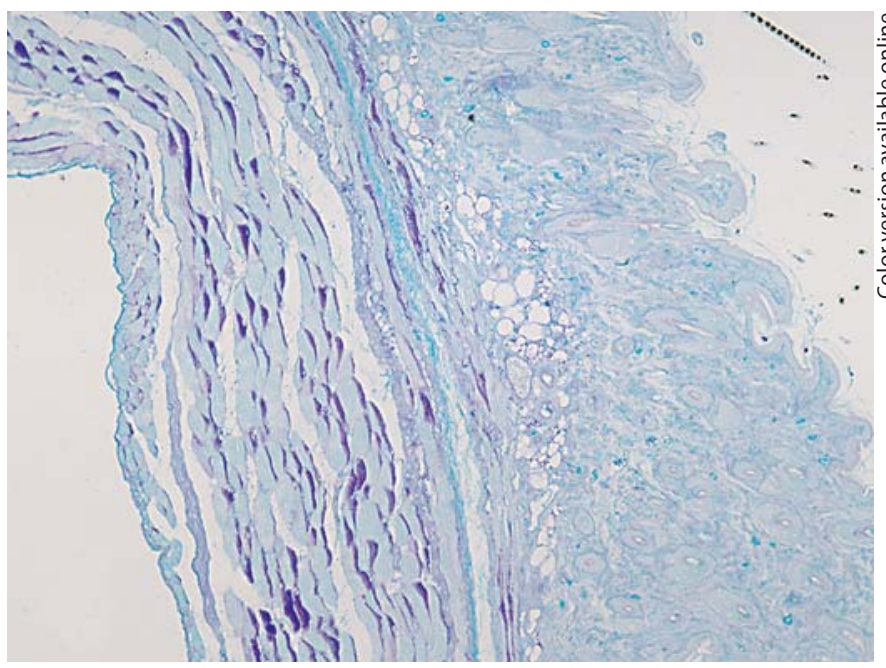

Fig. 5. Histochemical PAS and alcian blue ( $\mathrm{pH} 2.5)$ staining of the subcutaneous tissue from a control mouse. Histochemical stain. $\times 10$.

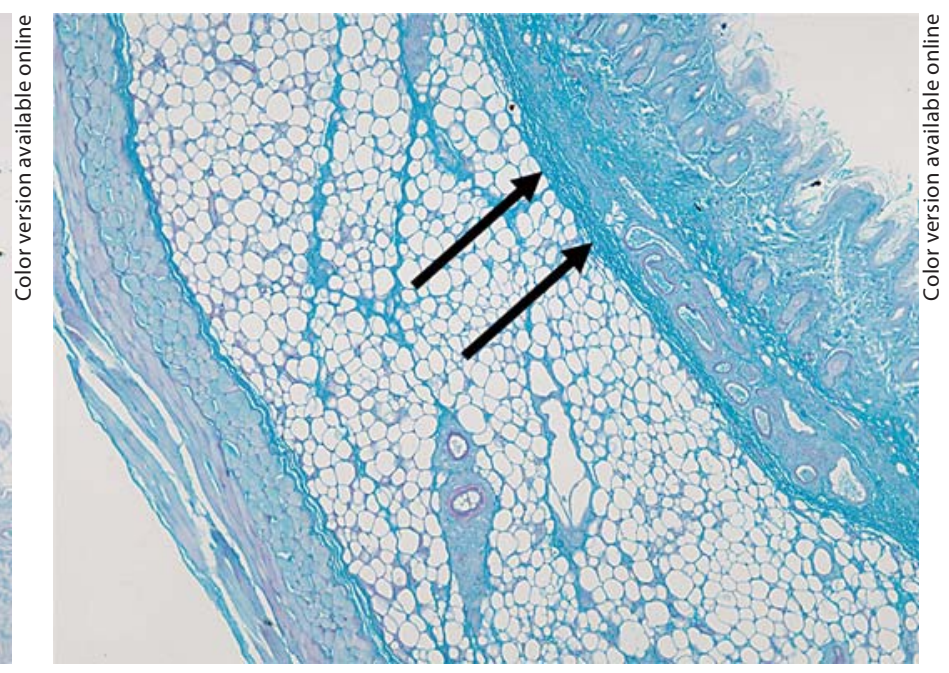

Fig. 6. Histochemical staining of the ECM in an op/op mouse subcutaneous tissue. Note that the ECM is PAS negative and stained dark blue with alcian blue at a $\mathrm{pH}$ of 2.5 (arrows). Histochemical stain. $\times 10$.

\section{Results}

Histologically, the bone marrow cavity and hematopoietic elements of the op/op mice were effaced by interweaving thick bony trabeculae consistent with osteopetrosis (fig. 1,2). No inflammatory, degenerative or vascular changes were noted. An increase in a finely granular, basophilic interstitial ECM was observed in the subcutaneous connective tissue of the op/op mice when compared with controls (fig. 3,4$)$. No evidence of skeletal muscle degeneration or necrosis was noted.

Histochemically, the ECM was PAS negative and stained dark blue with alcian blue at a $\mathrm{pH}$ of 2.5 , but not at $\mathrm{pH} 1$ or 0.4 (fig. 5, 6). There were no other tissue differ- 
ences between $o p / o p$ and control animals, although 2 of the oplop mice had an incidental background finding of retinal photoreceptor degeneration.

\section{Discussion}

Monocyte/macrophage colony-stimulating factor (MCSF) is a glycoprotein growth factor that stimulates the survival, proliferation and differentiation of mononuclear phagocytes (bone marrow precursor cell to monoblast to promonocyte to monocyte to macrophage) and osteoclasts $[9,10]$. There are 3 isoforms of CSF-1: (1) secreted glycoprotein, (2) proteoglycan and (3) cell surface glycoprotein [10]. CSF-1 receptor is selectively expressed on mononuclear phagocytes [9]. About $94 \%$ of circulating CSF-1 is selectively cleared by macrophages by receptormediated endocytosis and intracellular destruction [9]. CSF-1 is found in serum or plasma and has a circulating half-life of $10 \mathrm{~min}$ [9]. Macrophage depletion increases the half-life of circulating CSF-1 [9].

Osteopetrosis is a heterogeneous group of heritable conditions in which there is a defect in bone resorption by osteoclasts. This condition is associated with an increased skeletal mass due to abnormally dense bone [11]. In humans, there are 2 forms of osteopetrosis: (1) infantile osteopetrosis, an inherited autosomal recessive defect, and (2) autosomal dominant osteopetrosis [11]. Children with infantile osteopetrosis lack teeth and have unerupted or decayed teeth [12].

The oplop mice have been found to have an insertional mutation in the coding region of the M-CSF gene, and are subsequently severely deficient in macrophages and osteoclasts [13]. Therefore, these mice develop osteopetrosis. Other murine models of osteopetrosis include the RANKL knockout, RANK knockout, TRAP knockout and osteoprotegerin-transgenic mice [11]. The op/op mice in this study had increased bone density consistent with osteopetrosis and exhibited the characteristic traits of ostoeopetrosis, including missing incisors and domed skulls.

Hyaluronan (hyaluronic acid, HYA, and hyaluronate) is found in high concentrations in the connective tissues of vertebrates [14]. HYA is the predominant GAG found in loose connective tissues. HYA has a tissue half-life of $12 \mathrm{~h}$ to 3 days and is catabolized by receptor-mediated endocytosis and lysosomal degradation locally in macrophages [14]. The lowest concentration is found in blood serum and urine [14]. Histochemically, HYA stains with alcian blue at $\mathrm{pH}$ 2.5. In our study, the increased matrix appeared as a loosely arranged fibrillar or granular material that was alcian blue positive and PAS negative and was considered consistent with a mucinous material. The material separated and surrounded dense collagen bundles and caused slight expansion of the interstitium. The matrix stained dark blue with alcian blue at a $\mathrm{pH}$ of 2.5 only, but not at $\mathrm{pH} 1$ or 0.4 , indicating that it is composed primarily of nonsulfated GAGs. No abnormalities were evident in the collagenous matrix.

There is a significant reduction in the number of macrophages in various organs in the $o p / o p$ mouse model [15]. In addition, there is the lower population and/or the activity of macrophages which results in defective mineralization in the bone [16]. The increased matrix in connective tissues may be related to a decreased rate of matrix internalization and clearance by macrophages due to decreased numbers of macrophages. In the op/op mouse model, ECM maturation does not take place, indicating a role for monocyte-derived macrophages in ECM clearance. This hypothesis is further supported by demonstrating that ECM biosynthesis and release is monocyte/ macrophage density dependent in vitro studies [17]. Based on the histochemical findings in our study, the increase in matrix accumulation in connective tissues is probably related to an altered macrophage clearance mechanism of HYA. There are reports of HYA accumulation in cutaneous mucinosis, but this accumulation is not related to M-CSF inhibition. Impaired mucin degradation and enhanced mucin synthesis have been proposed as potential mechanisms of cutaneous mucinosis in humans, usually associated with thyroid disorders (hypothyroidism and hyperthyroidism). It is important to note that mucinous accumulation changes usually resolve following thyroid hormone supplementation [18]. Significant increases in concentrations of parafollicular cells in the thyroid gland are seen in osteopetrotic mice when compared with normal littermates during the first 3 months after birth. However, the parafollicular cell density 8 and 10 months after birth is not different and concentration of parafollicular cells returns to normal after bone matrix synthesis is reduced [19]. This is consistent with our study in which the mice used were of young age (4 weeks old).

Inherited retinal degeneration is widespread among laboratory mice and has been documented in various strains of mice around the world [20,21]. Retinal degeneration characterized by loss of photoreceptors is reported as an autosomal recessive trait in Swiss-derived strains of mice, including SJL mice [22], and the allele responsible is designated as $r d$ [23]. In this study, 2 mice from the $o p / o p$ group had bilateral retinal degeneration character- 
ized by loss of the outer photoreceptor layer. This finding is consistent with previously reported work that affected both pigmented and albino mice with complete loss of photoreceptors [22-25].

In conclusion, our work suggests that there is increased ECM that is composed mainly of GAGs located in the subcutaneous tissue in op/op mice. This increase in the
ECM may be related to altered matrix production or turnover because of changes in M-CSF production. Potential future studies may include: (1) effects of M-CSF injection or macrophage substitution on ECM accumulation and (2) quantification of subcutaneous macrophages to investigate macrophage HYA clearance.

\section{References}

1 Wiktor-Jedrzejczak W, Bartocci A, Ferrante AW Jr, Ahmed-Ansari A, Sell KW, Pollard JW, Stanley ER: Total absence of colonystimulating factor 1 in the macrophage-deficient osteopetrotic (op/op) mouse. Proc Natl Acad Sci USA 1990;87:4828-4832.

2 McCary LC, Smith CM, DeLuca HF: Hypophosphatemia and the development of rickets in osteopetrotic (op/op) mice. J Bone Miner Res 1997;12:1944-1951.

-3 Naito M, Hayashi S, Yoshida H, Nishikawa S, Shultz LD, Takahashi K: Abnormal differentiation of tissue macrophage populations in 'osteopetrosis' (op) mice defective in the production of macrophage colony-stimulating factor. Am J Pathol 1991;139:657-667.

-4 Ida-Yonemochi H, Noda T, Shimokawa H, Saku T: Disturbed tooth eruption in osteopetrotic (op/op) mice: histopathogenesis of tooth malformation and odontomas. J Oral Pathol Med 2002;31:361-373.

5 Kodama H, Yamasaki A, Nose M, Niida S, Ohgame Y, Abe M, Kumegawa M, Suda T: Congenital osteoclast deficiency in osteopetrotic (op/op) mice is cured by injections of macrophage colony-stimulating factor. J Exp Med 1991;173:269-272.

-6 Marks SC Jr, Wojtowicz A, Szperl M, Urbanowska E, MacKay CA, Wiktor-Jedrzejczak W, Stanley ER, Aukerman SL: Administration of colony stimulating factor-1 corrects some macrophage, dental, and skeletal defects in an osteopetrotic mutation (toothless, tl) in the rat. Bone 1992;13:8993.

7 Wiktor-Jedrzejczak W, Urbanowska E, Aukerman SL, Pollard JW, Stanley ER, Ralph P, Ansari AA, Sell KW, Szperl M: Correction by CSF-1 of defects in the osteopetrotic op/ op mouse suggests local, developmental, and humoral requirements for this growth factor. Exp Hematol 1991;19:1049-1054.
8 Carson FL: Carbohydrates and amyloid; in Carson FL: Histotechnology: A Self-Instructional Text, ed 1. Chicago, ASCP Press, 1990, pp 117-137.

-9 Bartocci A, Mastrogiannis DS, Migliorati G, Stockert RJ, Wolkoff AW, Stanley ER: Macrophages specifically regulate the concentration of their own growth factor in the circulation. Proc Natl Acad Sci USA 1987;84: 6179-6183.

10 Ryan GR, Dai XM, Dominguez MG, Tong W, Chuan F, Chisholm O, Russell RG, Pollard JW, Stanley ER: Rescue of the colony-stimulating factor 1 (CSF-1)-nullizygous mouse $\left(C s f 1^{o p} / C s f 1^{o p}\right)$ phenotype with a CSF-1 transgene and identification of sites of local CSF-1 synthesis. Blood 2001;98:74-84.

11 Tolar J, Teitelbaum SL, Orchard PJ: Osteopetrosis. N Engl J Med 2004;351:2839-2849.

12 Droz-Desprez D, Azou C, Bordigoni P, Bonnaure-Mallet M: Infantile osteopetrosis: a case report on dental findings. J Oral Pathol Med 1992;21:422-525.

13 Yoshida H, Hayashi S, Kunisada T, Ogawa M, Nishikawa S, Sudo T, Shultz LD, Nishikawa $\mathrm{S}$ : The murine mutation osteopetrosis is in the coding region of the macrophage colony stimulating factor gene. Nature 1990;345: 442-444.

14 Fraser JR, Laurent TC, Laurent UB: Hyaluronan: its nature, distribution, functions and turnover. J Intern Med 1997;242:27-33.

-15 Wiktor-Jedrzejczak W, Ratajczak MZ, Ptasznik A, Sell KW, Ahmed-Ansari A, Ostertag W: CSF-1 deficiency in the op/op mouse has differential effects on macrophage populations and differentiation stages. Exp Hematol 1992;20:1004-1010.
6 Sakagami N, Amizuka N, Li M, Takeuchi K, Hoshino M, Nakamura M, Nozawa-Inoue K, Udagawa N, Maeda T: Reduced osteoblastic population and defective mineralization in osteopetrotic (op/op) mice. Micron 2005;36: 688-695.

17 Uhlin-Hansen L, Kolset SO: Cell density-dependent expression of chondroitin sulfate proteoglycan in cultured human monocytes. J Biol Chem 1988;263:2526-2531.

18 Schaeffer D, Bruce S, Rosen T: Cutaneous mucinosis associated with thyroid dysfunction. Cutis 1983;32:449-452.

19 Marks SC, Lane PW: Osteopetrosis, a new recessive skeletal mutation on chromosome 12 of the mouse. J Hered 1976;67:11-18.

20 Drager UC, Hubel DH: Studies of visual function and its decay in mice with hereditary retinal degeneration. J Comp Neurol 1978; $180: 85-114$.

21 Sidman RL, Green MC: Retinal degeneration in the mouse: location of the $r d$ locus in linkage group XVII. J Hered 1965;56:23-29.

22 Caffe AR, Szel A, Juliusson B, Hawkins R, van Veen T: Hyperplastic neuroretinopathy and disorder of retinal epithelial cells precede accelerated retinal degeneration in the SJL/N mouse. Cell Tissue Res 1993;271:297307.

23 Lawrence WB: Diagnostic exercise: retinal lesions in a mouse. Lab Anim Sci 1990;40: 634-635.

24 Kircher $\mathrm{CH}$ : Pathology of the eye; in Benirschke K, Garner FM, Jones TC (eds): Pathology of Laboratory Animals. New York, Springer, 1978, vol 1, pp 640-642.

25 Tannsley K: An inherited retinal degeneration in the mouse. J Hered 1954;45:123-127. 